\title{
A new species of ischnacanthiform acanthodian from the Givetian of Mimerdalen, Svalbard
}

\author{
Michael J. Newman', Carole J. Burrow² \& Jan L. den Blaauwen ${ }^{3}$ \\ ${ }^{1}$ Vine Lodge, Vine Road, Johnston, Haverfordwest, Pembrokeshire, SA62 3NZ, UK. \\ ${ }^{2}$ Geosciences, Queensland Museum, 122 Gerler Road, Hendra, 4011 Queensland, Australia. \\ ${ }^{3}$ University of Amsterdam, Science Park 904, 1098 XH Amsterdam, The Netherlands. \\ E-mail corresponding author (Michael J. Newman): ichthyman@btinternet.com
}

A new ischnacanthiform acanthodian Serradentus armstrongi nov. gen. et sp. has been collected from the Middle Devonian (Givetian) Fiskekløfta Member, the upper member of the Tordalen Formation in the Mimerdalen Subgroup of Spitsbergen. The specimen comprises both pairs of upper and lower jaw bones, jaw cartilages, tooth or denticle whorls, dentition cones and spiky denticles. The latter two features have previously only been identified in Early Devonian ischnacanthiforms. The geology is consistent with a depositional environment of a brackish backwater lagoon with an anoxic bottom. The fish probably entered the lagoon during storm action and died due to the storm churning up bottom anoxic waters, or from being trapped and killed by hypersalinity. The fish possibly partially decomposed on the surface before the head detached and sank to the lagoon floor. The lack of scavengers due to the anoxic conditions prevented scattering of the individual elements, with denticles preserved along the labial surface of the dentigerous jaw bone, and jaw cartilage under the jaw bone.

Keywords: Lagoon, Devonian, histology, Spitsbergen, Arctic, Serradentus

Received 21. August 2019 / Accepted 02. December 2019 / Published online 14. January 2020

\section{Introduction}

An extensive vertebrate fauna has been collected from Fiskeløfta, in the Fiskeløfta Member of the Tordalen Formation of Spitsbergen (see Newman et al., 2019 for information on the geology and history of research in the area). Access to the site has improved in recent years, with the outcrop now free of snow cover for longer periods in the summer months, allowing collection of many new, impressive fossils including complete, metrelong coelacanths. Jaw bones assigned to Atopacanthus sp. from this locality were first mentioned by Ørvig (1957a), but not described until later that year (Ørvig, 1957b). The genus Atopacanthus Hussakof and Bryant, 1918 was erected for incomplete jaw bones from Frasnian deposits of Erie County, New York State (Burrow, 2004), and the type species Atopacanthus dentatus Hussakof and Bryant, 1918 was based on these remains. The genus has also been recorded from Germany (Jessen, 1973; Otto, 1999) and Russia (Novitskaya \& Obruchev, 1967; Beznosov, 2006). All occurrences are of isolated jaw bones, except for one articulated fish from Germany described by Jessen (1973).

The dentigerous jaw bones from the Fiskeløfta Member which Ørvig (1957b) assigned to Atopacanthus sp. include fairly complete specimens about $3-4 \mathrm{~cm}$ long, which he categorised as Type A (Ørvig, 1957b, fig. 15C; Fig. 1A) for those with a median tooth row, and Type B (Ørvig, 1957b, fig. 15A; Fig. 1B) for those lacking this row. He observed that they were closely related to the North American Atopacanthus, but the specimens he examined seem to have been quite worn (Fig. 1C, D \&

Newman, M.J., Burrow, C.J. \& den Blaauwen, J.L. 2019: A new species of ischnacanthiform acanthodian from the Givetian of Mimerdalen, Svalbard. Norwegian Journal of Geology 99, 619-631. https://dx.doi.org/10.17850/njg99-4-4. 

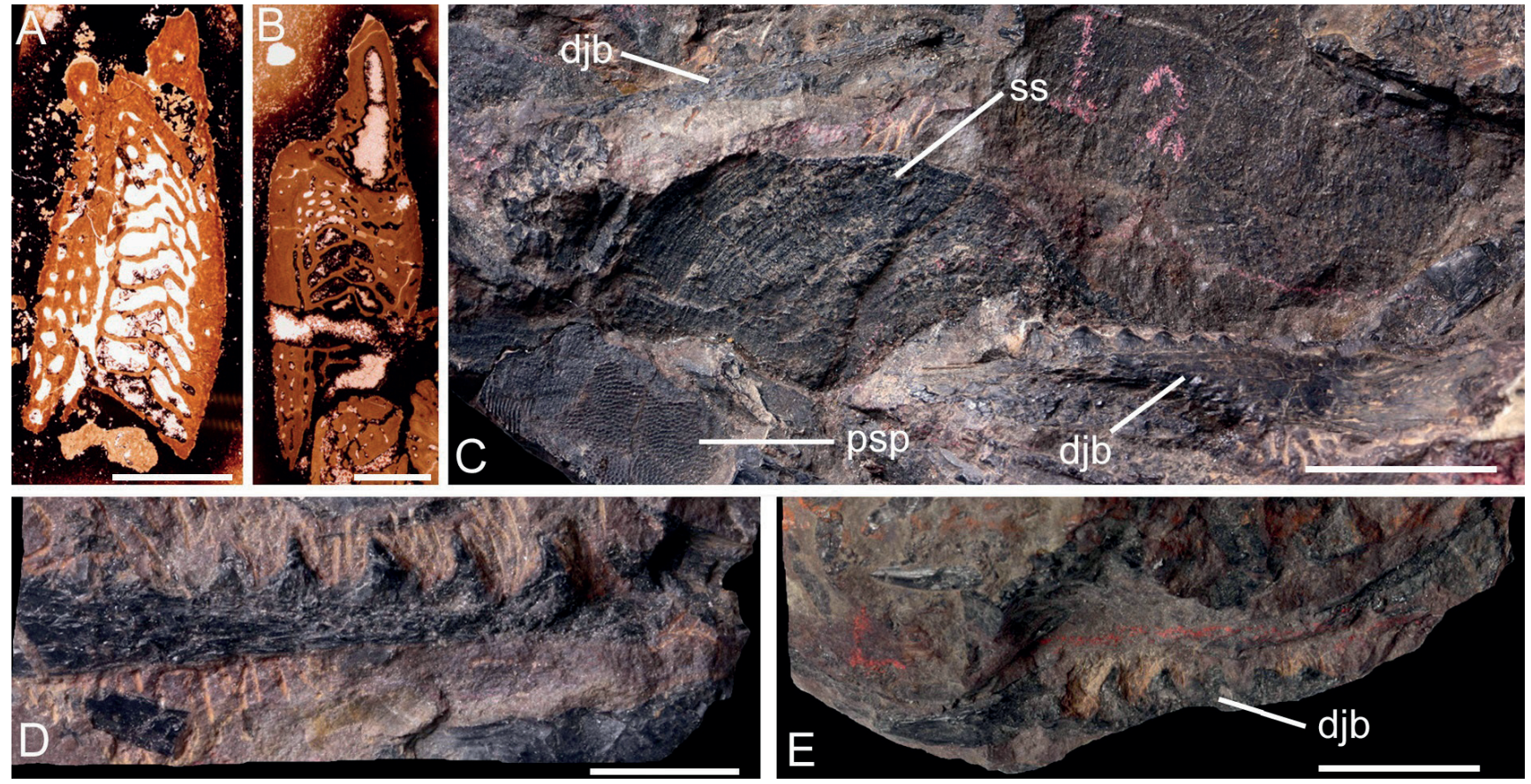

Figure 1. Ischnacanthiform jaws from Fiskeløfta. (A) NRM P.slide S141 Ørvig's 1957 Atopacanthus type A jaw. (B) NRM P.slide 144 Ørvig's 1957 Atopacanthus type B jaw (now synonymised with Serradentus armstrongi nov. gen. et sp.) (C) PMO A.2154 6 \& 7. (D) NRM P.5060. (E) NRM P.5061. djb - dentigerous jaw bone, psp - psammosteid plate, ss - sarcopterygian scale. Scale bars $=1 \mathrm{~mm}$ in $A \& B, 10 \mathrm{~mm}$ in $C \& E, 5$ $m m$ in $D$.

E). Here we describe new material from the same strata at Estheriahaugen North, which shows several newly recognised characters that prompt us to assign the Type $B$ form of jaw bones to a new genus and species.

\section{Materials and methods}

The material was found loose in ironstone nodules within a shale unit at the localities of Fiskeløfta and Estheriahaugen North (Lat. $78^{\circ} 39^{\prime} \mathrm{N}$, Long. $16^{\circ} 09^{\prime} \mathrm{E}$ ), both of which are considered to be the same bed (Newman et al., 2019). Only mechanical preparation was possible. Thin-sections were made by JdB along the edges of the rocksaw cut through the whole slab as well as through elements other than the set of jaws exposed on the slab, with slices prepared using epoxy resin and ground using various grain sizes of carborundum grinding powder down to 4 microns. Sections were photographed using a Sony DSC-H2 camera on a Nikon Eclipse E400 microscope. International collection abbreviations: PMO - Palaeontological collections of the Natural History Museum at the University of Oslo. NRM - Natural History Museum of Sweden, Stockholm.

\section{Depositional Environment}

The fauna, flora, geology and stratigraphy of the Fiskeløfta Member have been discussed in many papers (Newman et al., 2019 and references therein) but relatively little has been mentioned on the depositional environment. Of interest to this article is the exposure of unit 6 of Vogt (1941) of the Fiskeløfta Member (Fig. 2) on the northern side of Estheriahaugen (see Newman et al., 2019, fig. 1 locality map). Unit 6 at Estheriahaugen North (Fig. 3) consists of a 30 metre-thick, poorly stratified, brownish-black mudstone. Within this mudstone are two sandstone units c. one metre thick (Fig. 2) and a band of much thinner sandstone units (labelled A in Figs. 3 \& 4). The thicker sandstone units are sheet-like and continuous across the outcrop with no sorting or cross-bedding. The base of the lower thick sandstone unit in the outcrop (labelled B in Figs. $3 \& 4$ ) is covered in Cruziana trackways (Fig. 5). The thinner sandstone units range from just a few centimetres to 10 $\mathrm{cm}$ thick and are very variable and discontinuous across the entire outcrop. Below the lower thick sandstone unit is an abundance of rounded ironstone nodules containing fossil fish remains, commonly articulated, with some fully articulated (Fig. 2). They are particularly common around two metres below this sandstone unit at the same level as the thinner, discontinuous sandstone. Vertebrates preserved within these nodules include large sarcopterygians, psammosteids and coccosteids (all pers. obs.); the coccosteids appear to be absent in 


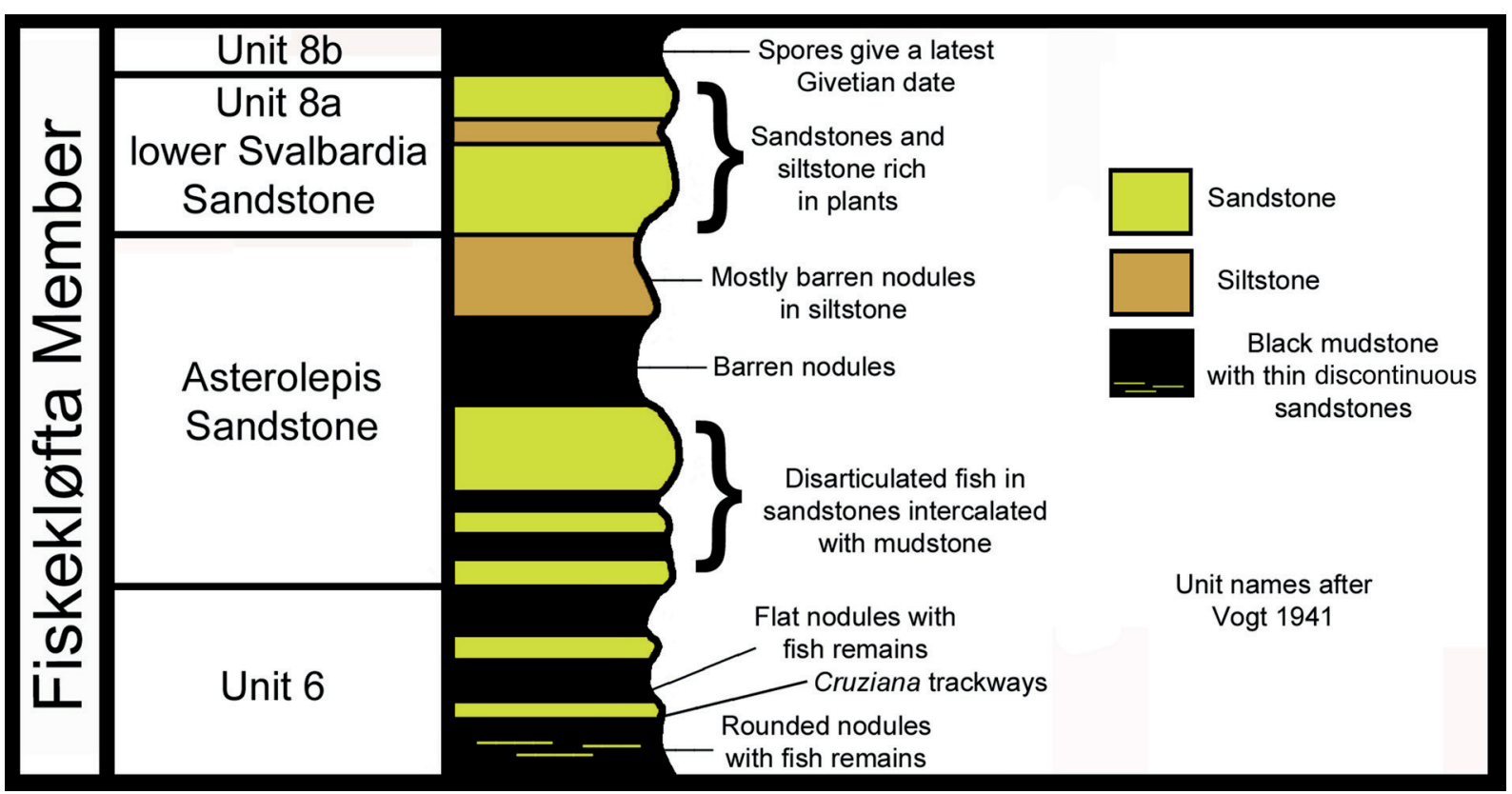

Figure 2. Stratigraphical column of the Fiskeløfta Member at Estheriahaugen North partly based on Piepjohn \& Dallmann (2014, fig. 5).

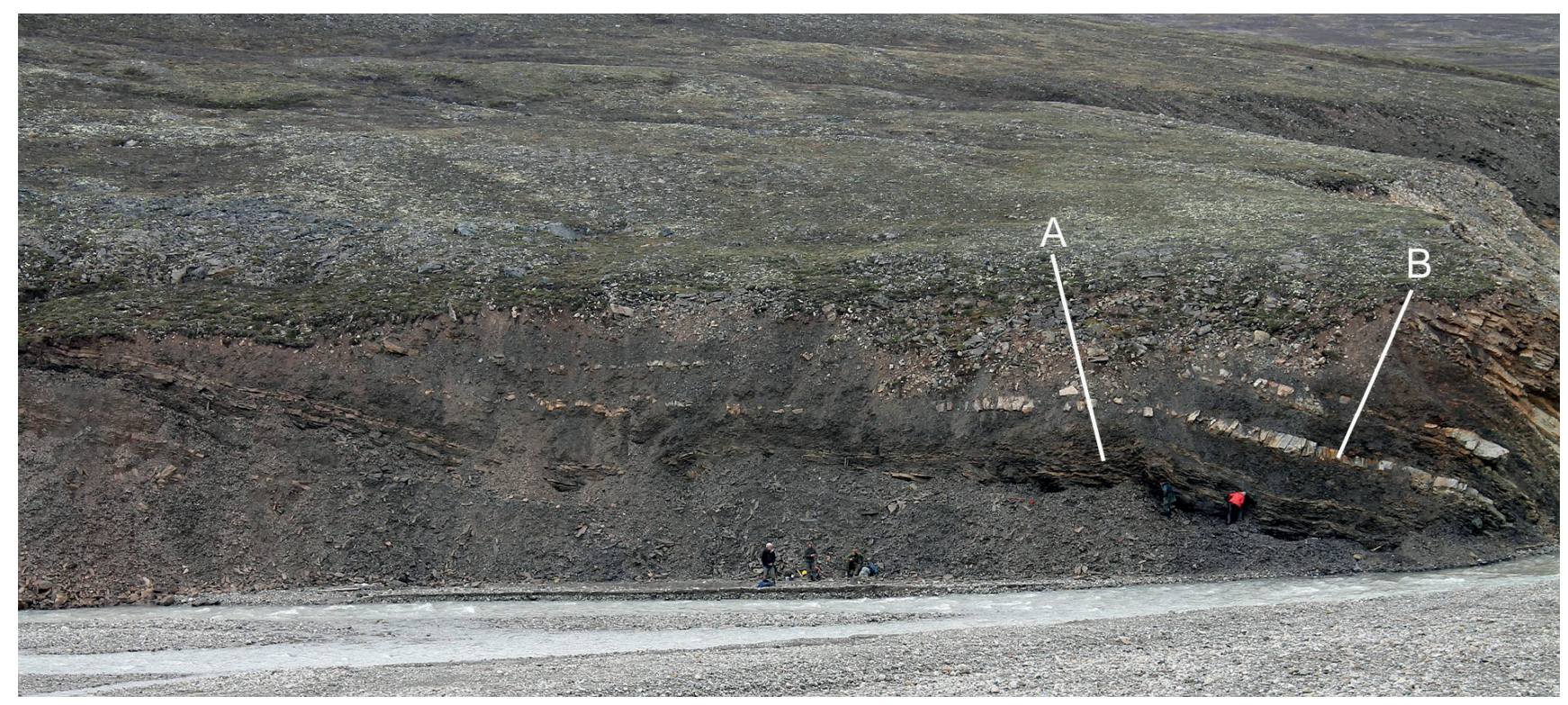

Figure 3. Estheriahaugen North. View of the outcrop. (A) is the most productive level of the mudstones with articulated fish in nodules between thin sandstone units and (B) the sandstone unit with Cruziana trackways at the base. John Armstrong (for whom the new species is named) is first from left.

higher strata. Above the lower thick sandstone unit are thinner ironstone nodules rich in acanthodians and actinopterygians. These remains are generally wellpreserved and articulated. Fish remains become rarer in the higher strata but are still found within nodules at the top of unit 6 (Fig. 2). In fact, just above and below the upper thick sandstone unit (Fig. 2) there is a relative abundance of nodules with articulated antiarchs and psammosteids as well as very large disarticulated sarcopterygians. However, these are still scarcer than in the underlying units.
The black mudstone contains acritarchs, but no other definitive marine fauna (Berry \& Marshall, 2015). A gastropod (Fig. 6) has been collected from the same strata at Estheriahaugen South but in its crushed state it is not identifiable to genus (R.T. Becker, pers. comm., 2018). This indicates a backwater marine environment, most likely a lagoon. The black mudstone would represent a warm wet high stand and the thicker sandstone units a cool arid regression, with the sands being reworked at the lagoonal edge (J. Marshall pers. comm., 2019). Alternatively, the thick sandstones could be short- 


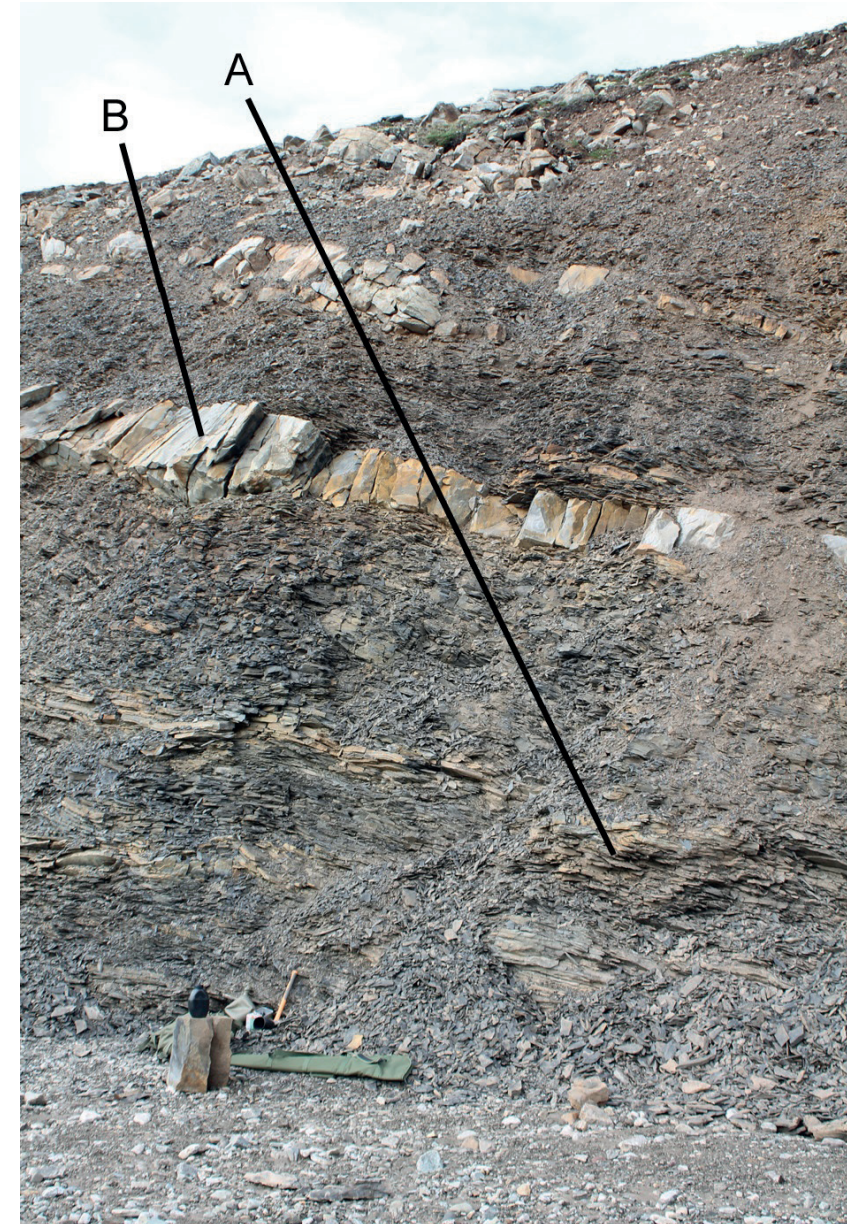

Figure 4. Detail of the stratigraphy at Estheriahaugen North, labelled as in Fig. 3. duration events where beach sands (barrier islands) have been broken through during storms and simply represent storm washovers (N. Davis pers. comm., 2019). The thinner sandstone units seem more likely to represent storm deposits as they are unsorted, uneven in thickness even as individual units and discontinuous across the outcrop. These units lack terrestrial detritus such as plant material which could indicate an alternative scenario such as a flash flood deposit. There are numerous coprolites within the black shale indicating that fish were present at some times in the water column above, but the coprolites are much less common than the fish remains. This disparity may indicate that the majority of the fish were washed into or entered the lagoon during storms, rather than living there long-term. The mudstones lack bioturbation and other evidence of scavenging, indicating an anoxic environment at the sediment-water interface, which is normally associated with a stratified water column. During violent storms the water would be churned up, causing mixing of the anoxic bottom water which could have caused mass mortality of the fish. However, the thin sandstone units (which would not normally be associated with anoxic depositional conditions) also lack bioturbation or any evidence of faunal activity, suggesting that a process other than anoxia could have caused at least some of the mortality. The lack of any other true marine fauna (other than the microscopic acritarchs mentioned above) indicates that there was a significant barrier (barrier islands?) from the open sea. If the normal environment in the lagoon was hypersaline, fish trapped there following storm surges could have died from hypersalinity rather than anoxia once the barrier reformed and 'normal' brackish to hypersaline conditions of the subtropical lagoon ensued.

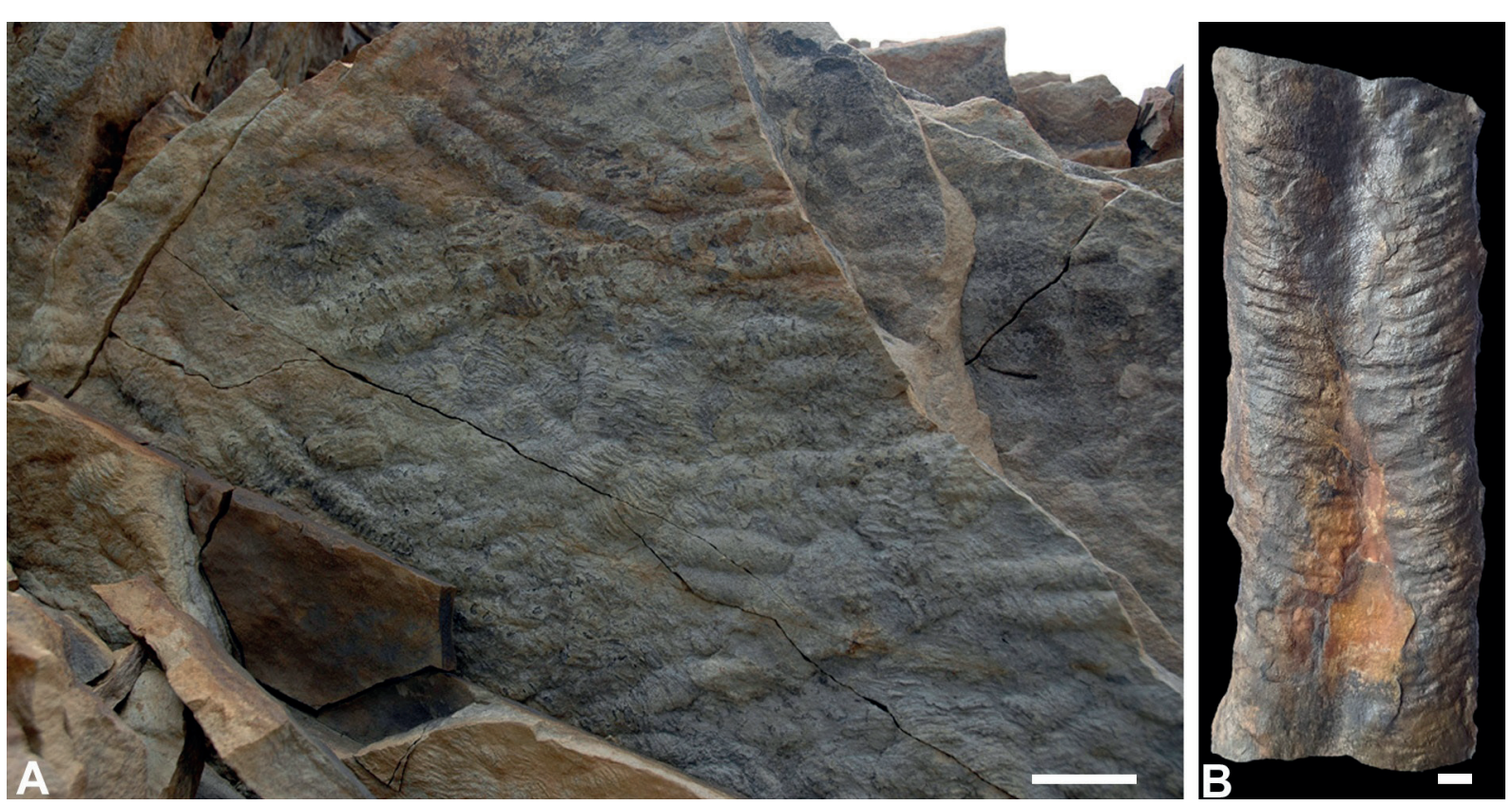

Figure 5. Cruziana sp. trackways at the base of the lowest thick sandstone unit at Estheriahaugen North. (A) View of tracks in situ. (B) PMO 234.599 closeup of a single trackway. Scale bars $=10 \mathrm{~cm}$ in $A, 10 \mathrm{~mm}$ in $B$. 

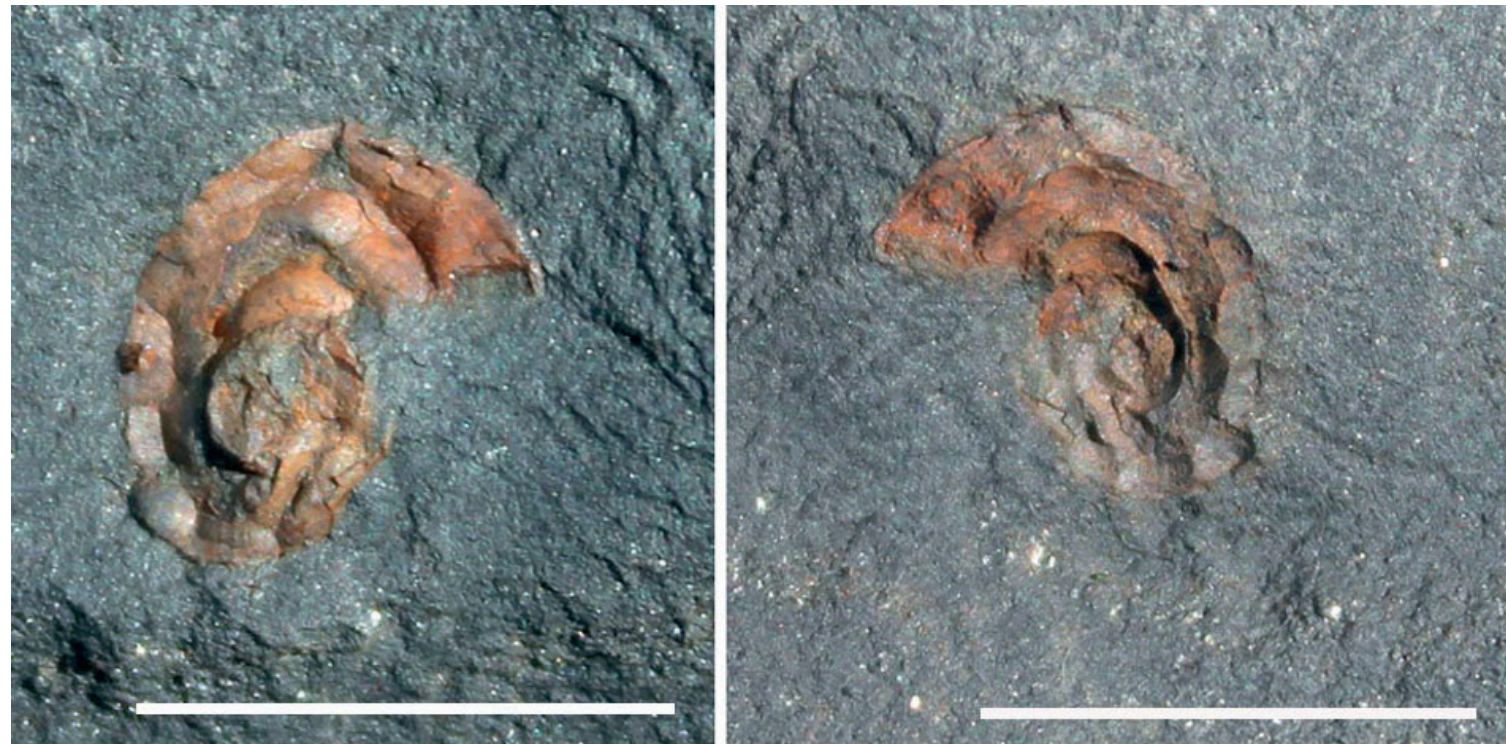

Figure 6. Gastropod from Estheriahaugen South. PMO 234.600. Scale bar $=10 \mathrm{~mm}$.

As noted earlier, the degree of preservation of carcasses varies greatly in the deposit. On dying, the fish would have sunk to the bottom of the lagoon and been preserved intact, or decayed while floating on the surface, with disarticulated bones (many isolated jaws are found, presumably falling off carcasses floating on the surface) dropping onto the lagoon floor (see Trewin, 1986, fig. 26). This scenario fits in with the style of preservation, as the nodules often have a perfectly preserved fish embedded within a detritus of bits of other fish of different species. The mudstones themselves also preserve a detritus of bits of fish, such as scales and teeth. The fish preserved within the thin sandstones (A in Figs. $3 \& 4)$ are rarer, but often very large and complete.

\section{SYSTEMATIC PALAEONTOLOGY}

\section{Order Ischnacanthiformes Berg, 1940}

Genus Serradentus nov. gen.

\section{Type species: Serradentus armstrongi}

Derivation of name: After serra, Latin for saw, and dente, Latin for tooth.

Included Taxa: Atopacanthus sp. NRM P 7718 from An der Loh quarry, Bergisch Gladbach, Germany.

Diagnosis: Ischnacanthiform acanthodian having jaw bones up to $60 \mathrm{~mm}$ long, with lateral row of c. 16 posteromedially curved teeth lacking side cusps; teeth increase in size from posterior to anterior of jaw bone; teeth with weakly striated/ridged lingual face, smooth labial face, and anterior and posterior carinae; carinae have serrations near the tooth base; posterior part of lower jaw bones flaring out laterally at about $70-80^{\circ}$ to long axis jaw bone, and posterior part of upper jaw bones flaring out laterally at about $30^{\circ}$ to long axis; thin, horizontal bone lamellae forming inner tissue of bone base; multiple small tooth whorls with five strongly striated, curved tooth cusps; dentition cones, with single row of denticles, in the mouth or branchial region; spiky denticles on labial face of dentigerous jaw bones; scales with wide thin crown ornamented with low sinuous subparallel longitudinal ridges, narrow neck, and flat thin base.

\section{Serradentus armstrongi sp. nov.}

?1918 in part Fragmente von Coccosteiden-Kiefern; Stensiö, p. 65.

1957 a Atopacanthus sp. in part; Ørvig, p. 393.

1957b Atopacanthus sp. in part; Ørvig, p. 285-287, 329, 337-344, figs. 14-15, pl. 2.

1979 A. sp. in part; Denison, p. 39.

1995 Atopacanthus in part; Burrow, p. 338.

1986 Atopacanthus sp. in part; Reed, p. 415.

1999 Atopacanthus type B (Spitsbergen); Otto, p. 117, table 1.

2004 Atopacanthus sp. Type B; Burrow, p. 263.

2004 Atopacanthus sp. in part; Long, Burrow \& Ritchie, p. 152.

2012 Atopacanthus in part; Voichyshyn \& Szaniawski, p. 883.

2019 Atopacanthus sp.; Newman, Burrow \& den Blaauwen, p. 4-5, 7.

Remarks: Ørvig (1957b) interpreted all mention of coccosteid jaws by Stensiö (1918) and later authors as mistaken identifications of Atopacanthus. However, jaws of an undescribed species of arthrodire are present in the 
same deposits as the ischnacanthiform remains and so this interpretation is not supported.

\section{Holotype: PMO 234.601}

Derivation of name: Named after John Armstrong of Edinburgh (see Fig. 3), one of the team that excavated Estheriahaugen North to yield the new fauna.

Diagnosis: Serradentus lacking a median tooth row on the dentigerous jaw bones.

Material: Oslo A21548; Uppsala P 474, P 491c; Stockholm NRM P 5060.

Type locality and horizon: Estheriahaugen North (Lat. $78^{\circ} 40^{\prime} \mathrm{N}$, Long. $\left.16^{\circ} 13^{\prime} \mathrm{E}\right) 3 \mathrm{~km}$ NE of the abandoned Russian mining town of Pyramiden, Spitsbergen, Svalbard, in the Fiskeløfta Member of the Mimerdalen Subgroup (late Givetian).

\section{Morphology:}

Dentigerous jaw bones. The holotype (Fig. 7) consists of four dentigerous jaw bones, with each bone being $54 \mathrm{~mm}$ long, plus calcified cartilage jaw remnants, tooth whorls, dentition cones, spiky denticles on the labial surface of the jaw bones, and scales with long wide crowns. The jaw elements are interpreted as representing one individual, with the left and right side jaws disarticulated. The dentigerous bones of the left jaw are those preserved on the left of the slab. The upper bone, with its labial face exposed, lies above the lower bone, with its lingual face exposed; the anterior end of both bones is to the right. The dentigerous bones of the right jaw lie to the right of the left side bones. However, the right upper bone, with its labial face exposed, has rotated by about $120^{\circ}$ and lies across the right lower bone, also with its labial face exposed. On each element, one row of evenly spaced monocuspid teeth are borne on a deep axial bone. The teeth increase in size from posterior to anterior, with the posteriormost teeth barely visible, and separated by sockets for the teeth of the opposing jaw (Fig. 8A); the anteriormost teeth are $4 \mathrm{~mm}$ high, decreasing in height posteriorly to less than $0.1 \mathrm{~mm}$. The teeth are posteromedially curved and fang-like, particularly the more anterior teeth which show little sign of wear or abrasion. The labial side of the teeth has two low vertical ridges extending down from the apex (Fig. $8 \mathrm{~B})$, the lingual side has four to six thin vertical ridges (Fig. 8C), and a carina is developed along each of the anterior and posterior sides (Fig. 8B). The teeth are oval in parabasal section. Each carina is serrated near the tooth base (Fig. 8B). There is a slight overlap between the carinae of adjacent teeth, with the anterior carina of the posteriormost tooth extending slightly labial to the posterior carina of the anterior tooth (Fig. 8B).

Both labial and lingual faces of the basal bone from both the upper and the lower jaws are smooth, without a row of teeth medial to the lateral tooth row. Very small denticles are randomly distributed on the low ridge medial to these main teeth, visible towards the posterior end of the left lower jaw bone (Fig. 8C). This jaw bone appears to have a weak trough between the lateral teeth and the

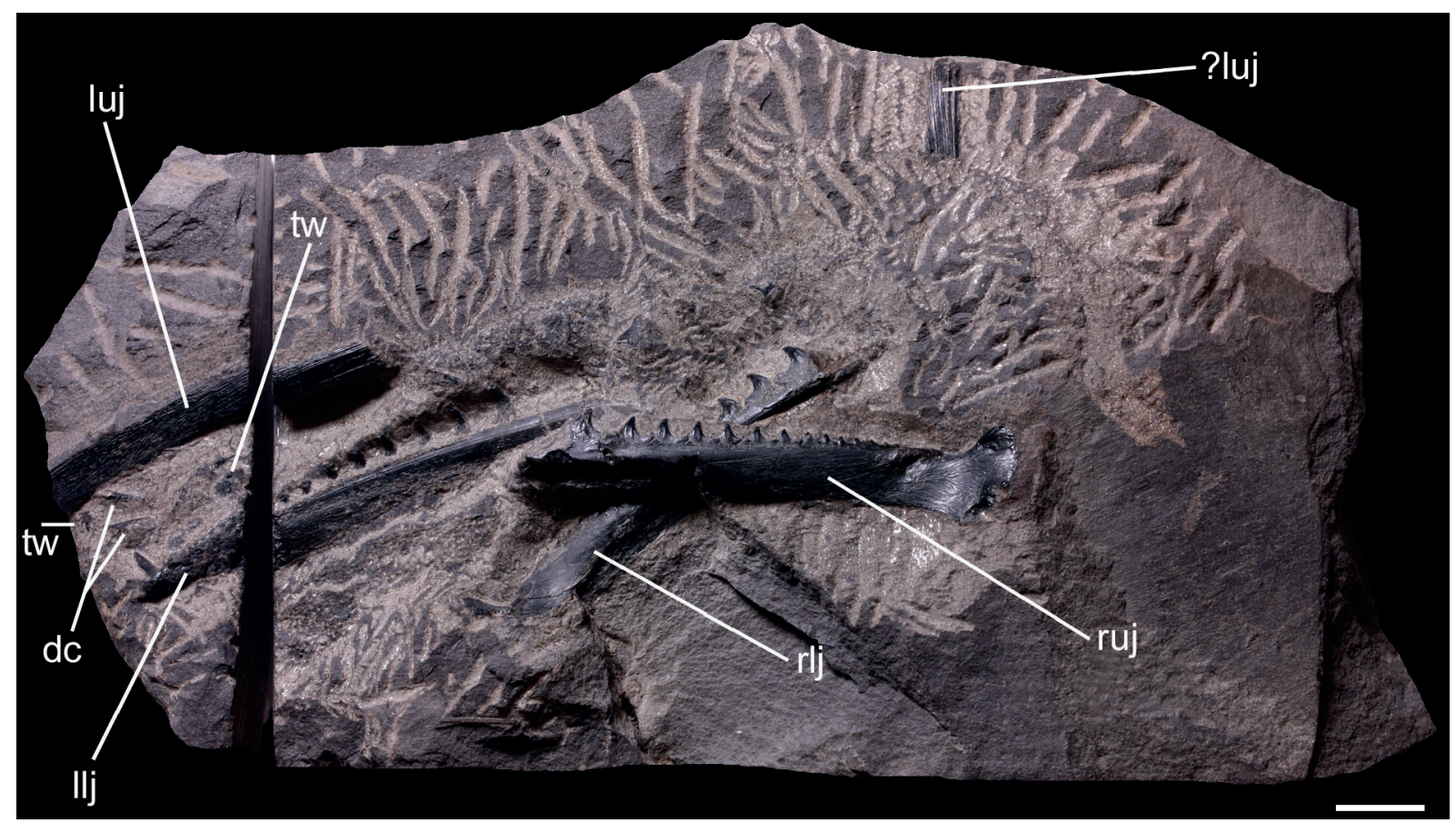

Figure 7. Serradentus armstrongi PMO 234.601 the holotype from Estheriahaugen North. dc - dentition cone, llj-left lower jaw in lingual view, luj-left upper jaw in lingual? view, rlj-right lower jaw in labial view, ruj-right upper jaw in labial view, tw - tooth whorl. Scale bar = $10 \mathrm{~mm}$. 

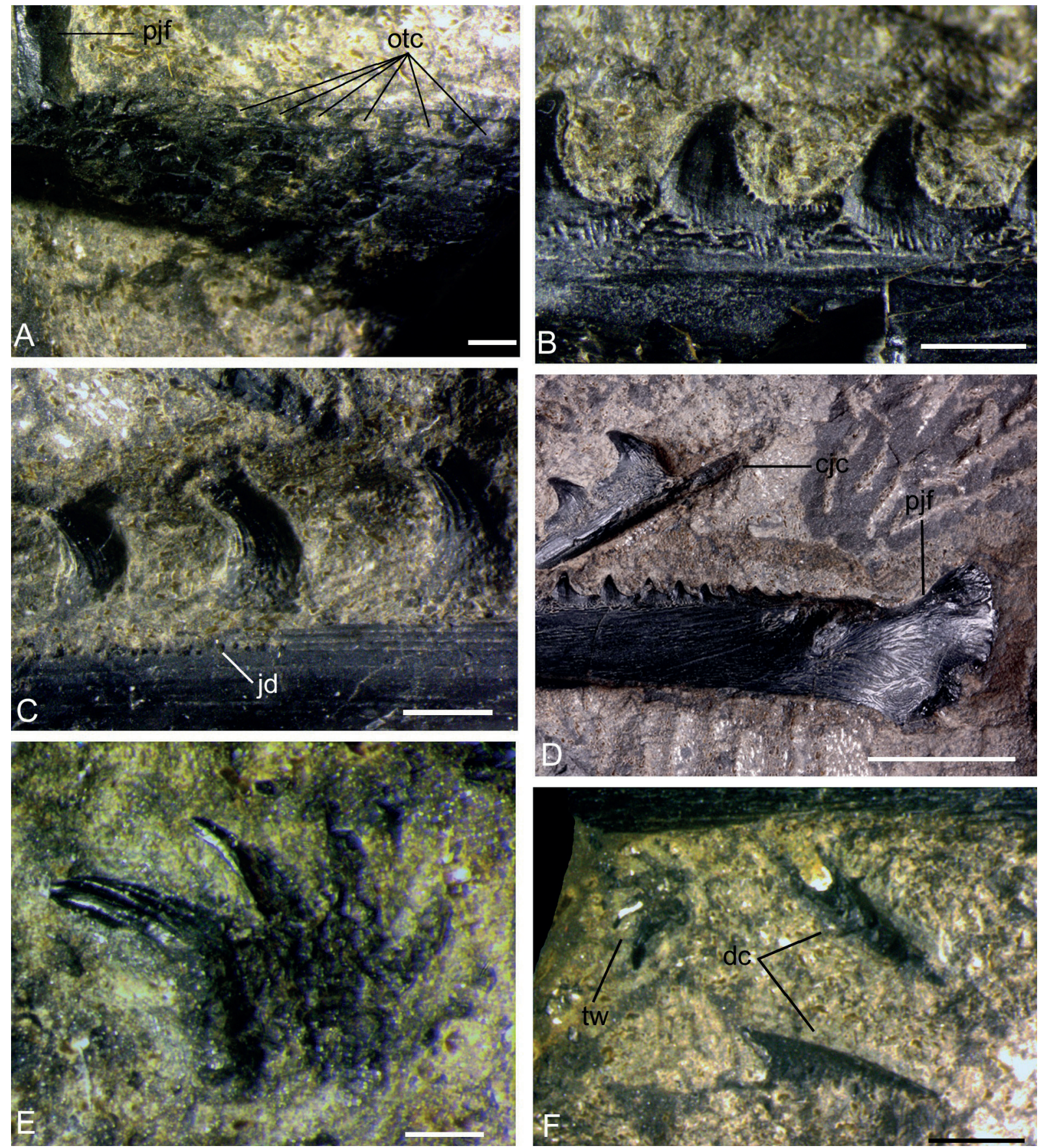

Figure 8. Serradentus armstrongi PMO 234.601 the holotype from Estheriahaugen North. (A) Posterior end of left lower jaw showing detail of sockets for opposing teeth. (B) Right upper jaw in labial view showing details of the teeth. (C) Left lower jaw in lingual view showing details of the teeth and lingual denticles. (D) Right upper jaw in labial view showing detail of the posterior jaw flange, and the right lower jaw in labial view showing details of the concavity for the jaw cartilage. (E) Tooth whorl. (F) Tooth whorl and dentition cones beneath left upper jaw. dcdentition cone, $j d$ - jaw denticles, otc - opposing tooth socket, pjf-posterior jaw flange, tw - tooth whorl. Scale bars = $1 \mathrm{~mm}$ in A, $2 \mathrm{~mm}$ in B, $C$ \& F, $10 \mathrm{~mm}$ in $D, 0.5 \mathrm{~mm}$ in $E$.

denticulated ridge. The axial bone extends forward of the anteriormost tooth; slices through the jaws show a concavity for the jaw cartilage (see histology description). The posterior end of the jaw bone flares out laterally behind the end of the tooth row, forming a longitudinally concave surface where the jaw musculature between the upper and lower jaws is confined (Fig. 8D). In the upper jaws the posterior flange is at about $30^{\circ}$ to the axis of the basal bone, and in the lower jaws it is at about $70-80^{\circ}$.
The flange on the lower jaw has a maximum height of 14 $\mathrm{mm}$, at its posterior limit, and the bone is about $8 \mathrm{~mm}$ high for most of its length. In transverse section, the jaw bones are markedly convex on the labial side, forward of the muscle concavity. Striae on the bone radiate obliquely forward and down from the posterior limit of the tooth row (Fig. 8D). A rugose area on the bone, in front of the muscle concavity near the posterior most tooth, probably represents an attachment for a labial cartilage. 
Tooth whorls, denticles and scales. Tooth whorls (Fig. 8E), dentition cones (Fig. 8F) and scales (Fig. 9) are also associated with the jaw bones. The tooth whorls have five curved pointed cusps which are strongly striated. There are two dentition cones exposed between the posterior end of the left lower bone and the upper bone of the holotype. They have a single row of denticles running from the base to the apex. These elements were probably originally in either the mouth or the branchial region based on comparison with the position in which they have been preserved in articulated ischnacanthiforms (e.g., Valiukevicius, 1992, 2003).

Separate small monocuspid teeth are also found scattered across the holotype nodule. They are not closely associated with the jaws like the dentition cones and tooth whorls, and are commonly found in most nodules containing various species at the Estheriahaugen site (MJN pers. obs.). Given their wider distribution, there is no certainty that they derive from the new species.

Large remnants of the jaw cartilages which are presumed to have borne the dentigerous jaw bones are also preserved in association within the matrix, with scattered calcified cartilage globules visible on the exposed surface of the slab.

Very few scales are preserved; they have low, sinuous, subparallel longitudinal ridges running the entire length of the scale crown, which is sub-rhombic in outline (Fig. 9), and wider and longer than the scale base. Maximum scale width is c. $1.0 \mathrm{~mm}$, maximum length c. $0.7 \mathrm{~mm}$. The neck is very narrow, and the base is thin and flat.

Histology:

Dentigerous jaw bones. Ørvig (1957b, figs. 14 \& 15) described and figured the structure of his Type A and

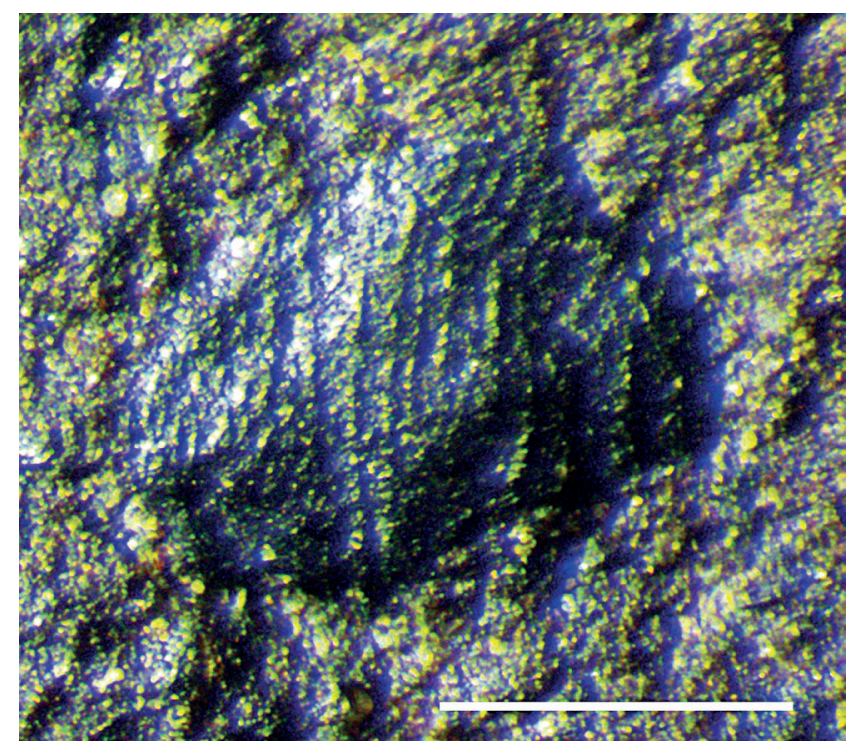

Figure 9. Serradentus armstrongi PMO 234.602 from Estheriahaugen North. Scale crown in dorsal view. Scale bar $=0.5 \mathrm{~mm}$.
Type B jaw bones from Estheriahaugen. Both types show the same histology in the structures common to both, i.e., the axial bone and lateral teeth, as detailed by Ørvig. Two of our thin sections (PMO 234.601/03, PMO 234.601/06) of PMO 234.601 (Fig. 10A) show the structure of the adentate detached anterior end of the dentigerous jaw bone (Fig. 10B), which appears rather disorganised, with convoluted lamellae and many longitudinal vascular canals surrounded by osteons. The concavity for the jaw cartilage is quite deep. PMO 234.601/09 (Fig. 10C) shows a more posterior part, which still shows the convoluted lamellations but here overlain by flatter lamellations so that the external surfaces appear much smoother. The concavity for the jaw cartilage is still quite deep at this level, possibly just anterior to the teeth. Bone cell lacunae and processes are present within the layers (Fig. 10D, E). PMO 234.601/10 (Fig. 10F) shows the structure of the jaw bone more posteriorly, where the lateral teeth are very small and worn; most of the tooth has broken and the section only shows the tooth base, which has a wide pulp cavity (Fig. 10F, G). Bone cell lacunae are visible, mainly in the lingual ridge. The cartilage concavity has been infilled by a layered spongiosa; a boundary is visible between the layers forming the axial bone and the infilling.

Layered remnants of the jaw cartilage, presumably of the left lower jaw, are visible in PMO 234.601/01, 02, 07, 08 \& 10 (Fig. 10H, I). The form of the cartilage resembles that recently identified in Cheiracanthus spp. from the Middle Devonian of Scotland (den Blaauwen et al., 2019). The cartilage mostly comprises contiguous subpolygonal blocks (Fig. 10J, K) with lines of Liesegang visible. In thicker cartilage layers, globular calcified cartilage with rings of Liesegang is present below the blocky cartilage (Fig. 10L).

Tooth whorls, denticles and scales. Small tooth whorls (Fig. 11A-F) are scattered through the matrix around the jaw bones and cartilages, sometimes clustered together (Fig. 11A). Most appear to have a median row of five cusps, each formed of orthodentine with a single central pulp cavity. As far as we can tell, the main cusps lacked secondary cusps. The bases of each cusp are separate and overlap those of the older cusps (Fig. 11F). The whorls are always associated with jaw cartilage, sometimes being preserved on the cartilage (Fig. 11C).

Arched spiky denticles formed of thin lamellae line the labial surface of the jaw bones (Figs. 10F \& 11G), and flatbased scales with an arched crown formed of the same type of thin lamellae (Fig. 11H, I \& J) are also scattered amongst the jaw cartilage remnants. The sections show that the scales have a high narrow neck and flat thin base, as well as the long thin crown observed in the scales exposed on the surface (Fig. 9).

Comparison: In having monocuspid lateral teeth and lacking medial teeth, the new species resembles 

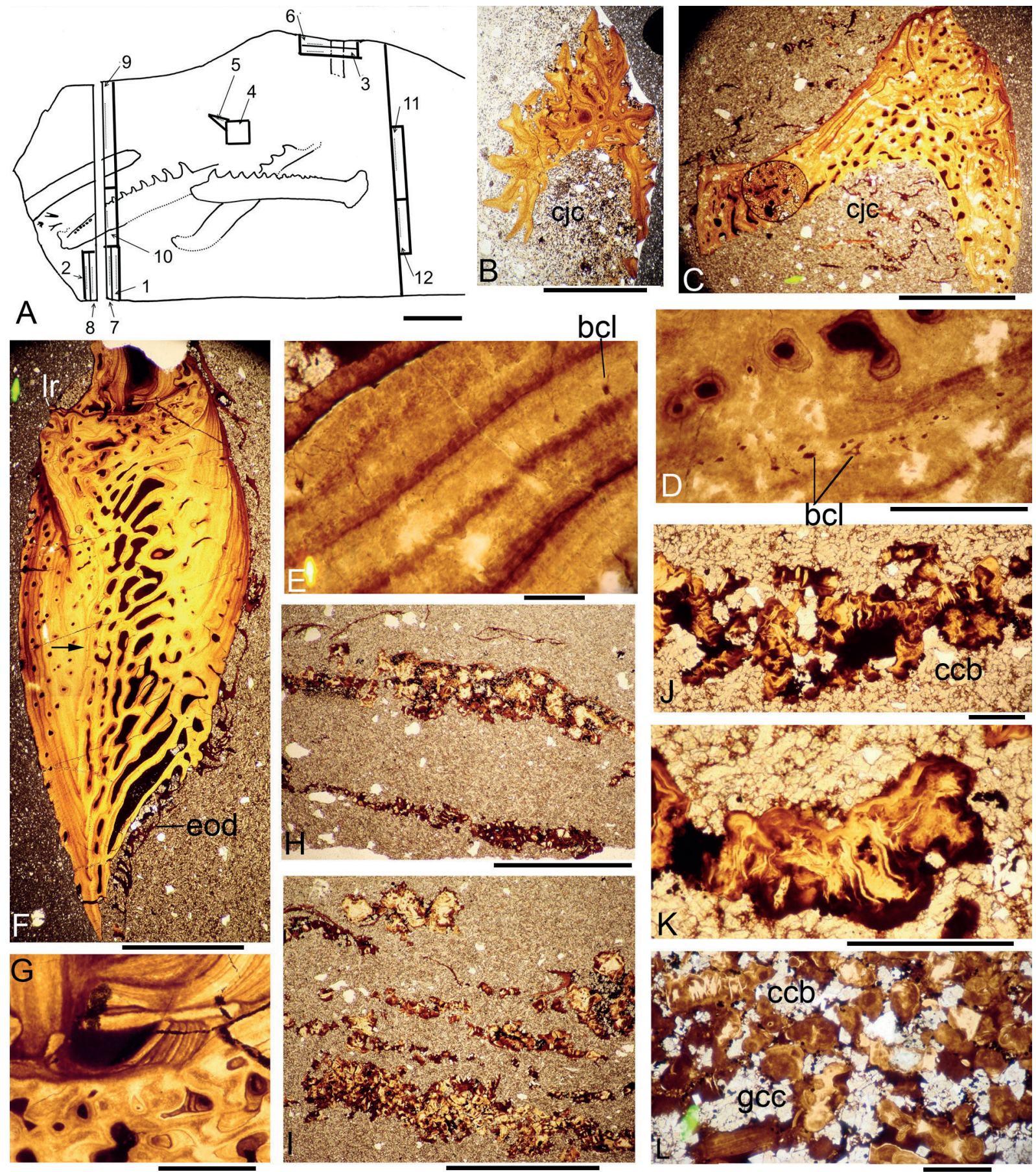

Figure 10. Serradentus armstrongi PMO 234.601601 the holotype from Estheriahaugen North. Jaw bone and cartilage histology. (A) Sketch of specimen showing position of thin-sections PMO 234.601/01-12. (B) PMO 234.601/09, detached anterior end probably of left upper jaw bone. (C, D \& E) PMO 234.601/09, near anterior end of left upper jaw bone, whole section and closeups of bone lamellae and bone cell lacunae and processes (F-G) PMO 234.601/10, towards posterior end of left lower jaw bone, occlusal surface to top, labial surface to right, latter coated with spiky scales/denticles. $(G)$ Closeup of osteons below tooth. (H-L) Sections through jaw cartilage presumed to be of lower left jaw: (H \& I) PMO 234.601/07. (J \& K) PMO 234.601/08. (L) PMO 234.601/10, cartilage just below jaw bone. bcl - bone cell lacunae, ccb - calcified cartilage blocks, cjc-concavity for jaw cartilage, eod-extraoral denticles, gcc-globular calcified cartilage. Scale bars $=20 \mathrm{~mm}$ in A, $0.5 \mathrm{~mm}$ in $B, E, G \& H, 0.1 \mathrm{~mm}$ in $C, D, F \& I-K$

Cacheacanthus utahensis Burrow, 2007 from the Emsian of Utah, U.S.A. However, Serradentus armstrongi nov. gen. et sp. differs from Cacheacanthus in having a robustly developed basal bone filled with bone lamellae, and serrations on the tooth carinae. The articulated fish (Fig. 12) from the Frasnian of Bergisch Gladbach, assigned to Atopacanthus sp. by Jessen (1973), also shows similarities with the Spitsbergen taxon, in the form of the lateral teeth, serrations on these teeth, the basal bone morphology and histology. However, the one notable 

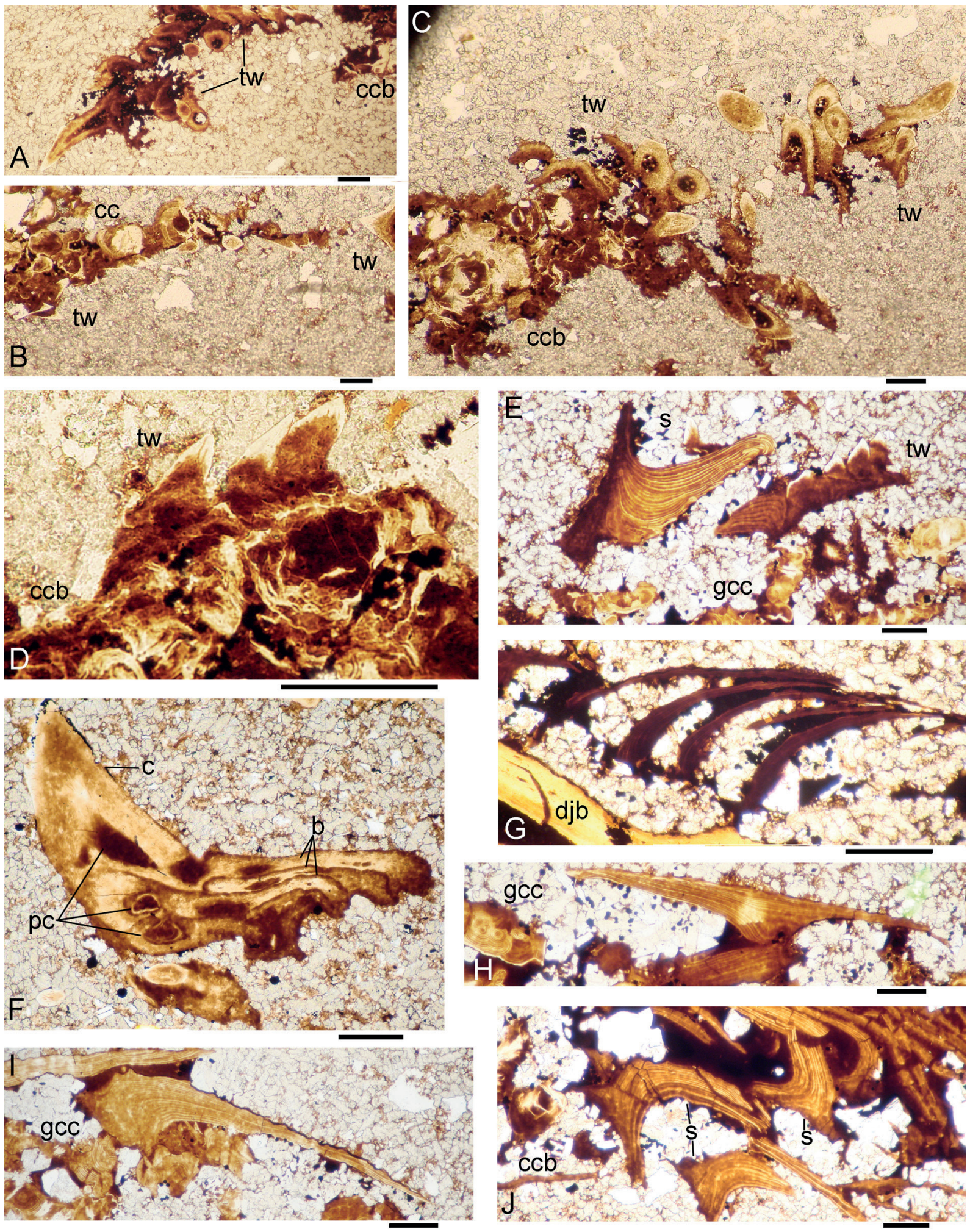

Figure 11. Serradentus armstrongi PMO 234.601 the holotype from Estheriahaugen North. Tooth whorl, denticle and scale histology. (A) PMO 234.601/08, oblique sections through tooth whorls (B \& C) PMO 234.601/02, oblique section through tooth whorls on calcified cartilage blocks, these two figure parts are contiguous on the section. (D) PMO 234.601/02, longitudinal section of tooth whorl on cartilage. (E) PMO 234.601/12, longitudinal section through tooth whorl and scale. (F) PMO 234.601/12, oblique vertical section through tooth whorl. (G) PMO 234.601/10, vertical longitudinal sections through denticles on labial surface of left lower dentigerous jaw bone. (H) PMO 234.601/11, transverse section through scale crown. (I) PMO 234.601/11, longitudinal section through scale. (J) PMO 234.601/11, longitudinal sections through scales. $b$ - cusp bases, $c$ - cusp, cc-calcified cartilage, ccb - calcified cartilage blocks, djb - dentigerous jaw bone, gccglobular calcified cartilage, $s$-scale, $t w$ - tooth whorl. Scale bars $=0.1 \mathrm{~mm}$. 


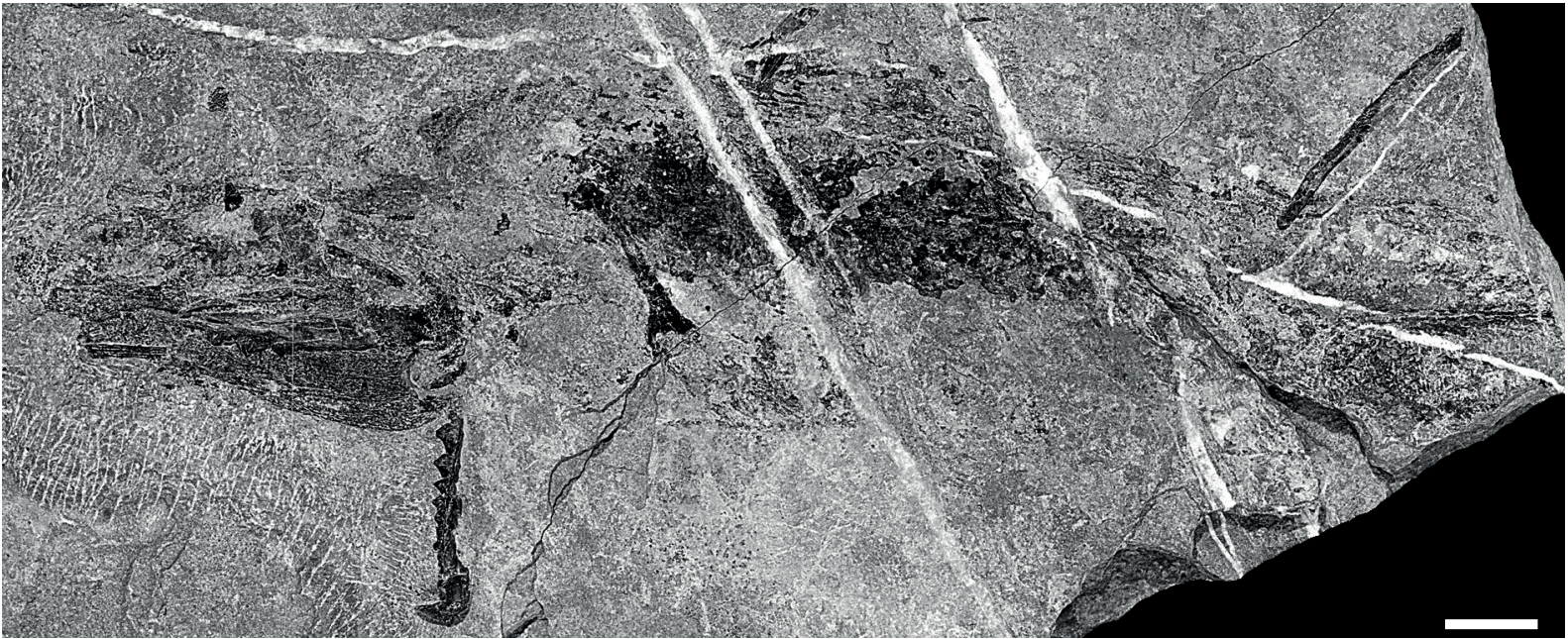

Figure 12. Serradentus sp. from An der Loh quarry, Bergisch Gladbach, Germany. NRM P.7718. Scale bar $=10 \mathrm{~mm}$.

difference is that the Bergisch Gladbach fish and the Type A jaw bones from Spitsbergen differ in having teeth and denticles on the lingual side of the jaw bone. Jessen (1973, plate 26) identified a disarticulated jaw bone with a strongly deflected posterior flange, near the jaws on the Bergisch Gladbach fish, as being from the lower jaw. If this is correct, then the dentigerous bones of Serradentus armstrongi nov. gen. et sp. showing a similar angle of deflection are interpreted as from the lower jaws, and the ones showing a low angle of deflection are from the upper jaws, as we have labelled them in the Description. The jaw bones of Atopacanthus? ambrockensis Otto, 1999 from the Middle Devonian (middle Eifelian) of Sauerland, Germany do not have serrations of the teeth. They bear a similarity to the type A jaw bones described by Ørvig (1957b) in having a medial tooth row, but differ in other features including having teeth which are more compressed labio-lingually, and having three not two carinae. Otto (1999) considered the holotype bone was from the lower jaw, and we agree with his conclusion as the posterior flange bends at a wide angle to the long axis of the bone. In the shape of the teeth, A.? ambrockensis seems more similar to younger species including Persacanthus simpsonensis Reed, 1986 from the ?Frasnian Red Hill fish fauna of Nevada, U.S.A. and Grenfellacanthus zerinae Long, Burrow \& Ritchie, 2004 from the Fammenian Hunter Formation of New South Wales, Australia.

The dentition cones are interesting as they represent by far the youngest record of such elements. Otherwise, they have only been described from Lower Devonian poracanthodid (Valiukevičius, 1992; Burrow, 1995) and acritolepid (Valiukevičius, 2003) ischnacanthiforms; they are not known to occur in ischnacanthid ischnacanthiforms (e.g., Ischnacanthus gracilis: Burrow et al., 2018). However, the same type of element, from the same locality as Atopacanthus? ambrockensis was described as an acanthodian gill raker by Otto (1999, fig.
2J). The spiky denticles which line the outside of the jaw bones are presumed to have been in the skin originally, and can be compared with the extraoral structures identified in Lower Devonian ischnacanthiforms (Blais et al., 2011; Burrow et al., 2018). The small tooth whorls resemble the multicuspid buccal and extraoral elements of Ischnacanthus gracilis (Burrow et al., 2018).

\section{Discussion}

Burrow (2004) suggested that a diagnostic character for Atopacanthus is the posterior flange only diverging at a low angle from the long axis of the jaw bone. The new material from Spitsbergen and the articulated fish described by Jessen (1973) from Germany, show that in Serradentus at least, the angle of divergence depends on whether the jaw bone is from the upper or lower jaw.

Determining the presence or absence of serrations on the teeth appears highly dependent on the preservation of the material. The lateral teeth on the holotype of Atopacanthus dentatus are poorly preserved, and the original presence or absence of serrations cannot be determined. Although most specimens assigned to $A$. dentatus appear to lack this feature, Burrow (2004, fig. $4 \mathrm{~B}, \mathrm{C}$ ) showed that at least one specimen assigned to the taxon has serrations on the posterior carina of some of the lateral teeth. However, the presence or absence of a medial tooth row is unknown for this specimen, so possibly it is from another species. The main difference between A. dentatus and Serradentus gen. nov. is the former having a median row of robust teeth which is lacking in the latter. 


\section{Conclusions}

The depositional environment in which the fish fauna at Estheriahaugen North was preserved was a backwater, possibly brackish lagoon. As coprolites are rarer than the actual fish remains, particularly at certain levels mentioned above, it seems reasonable to suggest that the majority of the fish lived outside the lagoon in an open marine environment. A number of the species from Estheriahaugen North, including the acanthodian Cheiracanthus intricatus (Valiukevičius, 2002; Newman et al., 2019), are also found in the marine deposits of the Baltic region. The fish possibly entered the lagoon through a break in a barrier during storms, subsequently dying when anoxic bottom waters of the lagoon were churned up by the storm rendering the whole lagoon anoxic, or later when the lagoon returned to 'normal' hypersalinity. On dying, the bodies of these fish either would have sunk to the bottom of the lagoon intact, or partially intact after gas buildup and subsequent partial decomposition, or as disarticulated bones after near-complete decomposition within the water column. Hence, they are commonly preserved as articulated fish within a debris of disarticulated remains of other species of fish. Another form of preservation is ironstone nodules full of disarticulated fish remains of many forms including acanthodians, porolepiforms and psammosteids such as seen in PMO A21548 (Fig. 1C). Both types of preservation are consistent with the normal conditions in the lagoon, with anoxic conditions near the sediment-water interface excluding scavengers and enabling good preservation of the fish remains.

Serradentus armstrongi nov. gen. is an ischnacanthiform that has features (e.g., dentition cones and spiky denticles) previously only identified in Early Devonian taxa. It had jaw cartilages showing a subtessellate structure similar to that in I. gracilis, as well as its contemporary Climatius reticulatus, and also Middle Devonian Cheiracanthus spp. (den Blaauwen et al., 2019). It is most closely related to the other Serradentus sp. from the same deposits, with the main difference being the lack of a lingual tooth row in S. armstrongi.

The scales of Serradentus armstrongi differ markedly from those described in other ischnacanthiforms. Ischnacanthids have smooth crowned scales with a convex base; poracanthodids have scales with a network of pore canals through the crown which is ornamented with ridges, or smooth; and acritolepids have convexbased scales with crowns ornamented with short ridges running back from the anterior edge. We speculate that the scales of Serradentus could have derived from the poracanthodid type, with loss of the pore canal system.
Acknowledgements. MJN would like to thank Professor John Marshall (University of Southampton) and Dr Chris Berry (Cardiff University) for inviting him to do the original fieldwork in Mimerdalen. The authors would further like to thank John Marshall for providing the figure used in Fig. 5A. MJN would also like to thank fellow fieldworkers, Roger Jones (London), Patrick and Robert Gavin (Glasgow), Tormi Tuuling (Tallinn), John Armstrong (Edinburgh), Chris and Alex Moore (Charmouth) and Steven Waters (Dollar, Clackmannanshire) for their very hard work in the field clearing the considerable scree from Estheriahaugen North's cliff face. MJN would also like to thank the staff at the Tulip Hotel in Pyramiden for all their assistance, and Sergey Chernikov of the Grumant Arctic Travel Company for help with logistics. The authors thank Franz-Josef Lindemann at the Natural History Museum at the University of Oslo for access to specimens in his care, and Dr Thomas Mörs and Khaled Abo at the Natural History Museum of Sweden, Stockholm for access to specimens in their care and for providing photographs of some of these. The authors particularly thank Professor Lars Werdelin at the Natural History Museum of Sweden, not only for access to the collections, but also providing the photograph used in Fig. 12. The authors also thank Professor Ralph Thomas Becker of the University of Münster for discussions on the invertebrate fauna found at Mimerdalen. The authors would also like to thank Dr Neil Davies (University of Cambridge) for discussion of the sedimentology of Estheriahaugen North. CJB acknowledges the support of the Queensland Museum. Finally, the authors would like to thank the two reviewers, Professor Hans Arne Nakrem (University of Oslo) and Professor Kate Trinajstic (Curtin University) for their insightful comments.

\section{References}

Berg, L.S. 1940: Classification of fishes, both recent and fossil. Trudy Instituta Zoologicheskikh Akademiia Nauk 5, 85-517.

Berry, C.M. \& Marshall, J.E.A. 2015: Lycopsid forests in the early Late Devonian paleoequatorial zone of Svalbard. Geology 43, 1043-1046. https://doi.org/10.1130/G37000.1.

Beznosov, P. 2006: Ischnacanthid jaw bones from the Frasnian of the East European Platform: Atopacanthus or Persacanthus? In Yang, Q., Wang, Y.-D., \& Weldon, E.A. (eds.): Ancient Life and Modern Approaches - 2nd International Palaeontological Congress, University of Science and Technology of China Press, Beijing China, pp. 326-327.

Blais, S.A., MacKenzie, L.A. \& Wilson, M.V.H. 2011: Tooth-like scales in Early Devonian eugnathostomes and the 'Outside-In' hypothesis for the origins of teeth in vertebrates. Journal of Vertebrate Paleontology 31, 1189-1199.

https://doi.org/10.1080/02724634.2011.607992.

den Blaauwen, J.L., Newman, M.J. \& Burrow, C.J. 2019: A new cheiracanthid acanthodian from the Middle Devonian (Givetian) Orcadian Basin of Scotland and its biostratigraphic and biogeographical significance. Scottish Journal of Geology, 166-177. https://doi.org/10.1144/sjg2018-023.

Burrow, C.J. 1995: Acanthodian dental elements from the Trundle Beds (Lower Devonian) of New South Wales. Records of the Western Australian Museum 17, 331-341.

Burrow, C.J. 2004. A redecription of Atopacanthus dentatus Hussakot and Bryant, 1918 (Acanthodii, Ischnacanthidae). Journal of Vertebrate Paleontology 24, 257-267. https://doi.org/10.1671/1928.

Burrow, C.J. 2007: Early Devonian (Emsian) acanthodian faunas of the western USA. Journal of Paleontology 81, 824-840. https://doi.org/10.1666/pleo06-009.1.

Burrow, C.J., Newman, M., Blaauwen, J.D., Jones, R. \& Davidson, R. 2018: The Early Devonian ischnacanthiform acanthodian Ischnacanthus gracilis (Egerton, 1861) from the Midland Valley of Scotland. Acta Geologica Polonica 68, 335-362. 
Denison, R.H. 1979: Acanthodii. In Schultze, H.-P. (ed.): Handbook of Paleoichthyology, Part 5, Gustav Fischer Verlag, Stuttgart and New York, pp. 1-62.

Hussakof, L. \& Bryant, W.L. 1918: Catalog of the fossil fishes in the Museum of the Buffalo Society of Natural Sciences. Bulletin of the Buffalo Society of Natural Sciences 12, 1-346.

Jessen, H. 1973: Weitere Fischreste aus dem oberen Plattenkalk der Bergisch-Gladbach - Paffrather Mulde (Oberdevon, Rheinisches Schiefergebirge). Palaeontographica A 143, 159-187.

Long, J., Burrow, C. \& Ritchie, A. 2004: A new Late Devonian acanthodian fish from the Hunter Formation near Grenfell, New South Wales. Alcheringa 28, 147-156. https://doi.org/10.1080/03115510408619279.

Newman, M.J., Burrow, C.J. \& den Blaauwen, J.L. 2019: The Givetian vertebrate fauna from the Fiskekløfta Member (Mimerdalen Subgroup), Svalbard. Part I. Stratigraphic and faunal review. Part II. Acanthodii. Norwegian Journal of Geology 99, 1-16. https://doi.org/10.17850/njg99-1-01.

Novitskaya, L.J., \& Obruchev, D.V. 1967: Class Acanthodei; pp. 263-291. In Obruchev, D.V. (ed.): Fundamentals of Palaeontology, Vol. 11, Israel Program for Scientific Translation, Jerusalem (English translation from Russian).

Ørvig, T. 1957a: Remarks on the vertebrate fauna of the Lower Upper Devonian of Escuminac Bay, P. Q., Canada, with special reference to the Porolepiform Crossopterygians. Arkiv för Zoologi, series 2, 367-426.

Ørvig, T. 1957b: Notes on some Paleozoic lower vertebrates from Spitsbergen and North America. Norwegian Journal of Geology 37, 285-353.

Otto, M. 1999: New finds of vertebrates in the Middle Devonian Brandenberg Group (Sauerland, Northwest Germany). Paläontologische Zeitschrift 73, 113-131. https://doi.org/10.1007/BF02987986.

Piepjohn, K. \& Dallmann, W.K. 2014: Stratigraphy of the uppermost Old Red Sandstone of Svalbard (Mimerdalen Subgroup). Polar Research 33, 1-22.

https://doi.org/10.3402/polar.v33.19998.

Reed, J.W. 1986: The acanthodian genera Machaeracanthus and Persacanthus from the Devonian of Red Hill, Nevada. Geobios 19, 409-419. https://doi.org/10.1016/S0016-6995(86)80001-8.

Stensiö, E. 1918: Zur Kenntnis des Devons und des Kulms an der Klaas Billenbay, Spitsbergen. (On the understanding of the Devonian and the Culm at Klaas Billenbay, Spitsbergen). Bulletin of the Geological Institution of the University of Uppsala $16,65-80$.

Trewin, N.H. 1986: Palaeoecology and sedimentology of the Achanarras fish bed of the Middle Old Red Sandstone, Scotland. Transactions of the Royal Society of Edinburgh, Earth Sciences 77, 21-46. https://doi.org/10.1017/S0263593300010737.

Valiukevičius, J.J. 1992: First articulated Poracanthodes from the Lower Devonian of Severnaya Zemlya. In Mark-Kurik, E. (ed.): Fossil Fishes as Living Animals, Academy of Sciences of Estonia, Tallinn, pp. 193-214.

Valiukevičius, J.J. 2002: Early and Middle Devonian acanthodian associations of Lithuania with respect to the lithofacies. Litosfera 6, 30-39.

Valiukevičius, J.J. 2003: Devonian acanthodians from Severnaya Zemlya Archipelago (Russia). Geodiversitas 25, 131-204.

Vogt, T. 1941: Geology of a Middle Devonian cannel coal from Spitsbergen. Norwegian Journal of Geology 21, 1-12.

Voichyshyn, V. \& Szaniawski, H. 2012: Acanthodian jaw bones from Lower Devonian marine deposits of Podolia, Ukraine. Acta Palaeontologica Polonica 57, 879-896.

https://doi.org/10.4202/app.2011.0079. 